Article - Agronomy/Soil Science

\title{
Increasing the Productive Potential of an Ultisol using Cover Crops and Organic and Mineral Fertilization
}

\author{
Graziela Moraes de Cesare Barbosa ${ }^{1 \star}$ \\ https://orcid.org/0000-0003-2116-4736
}

\section{Antonio Costa ${ }^{1}$}

https://orcid.org/0000-0003-0269-8580

Marco Aurélio Teixeira Costa ${ }^{2}$

https://orcid.org/0000-0002-2164-5735

\section{José Francirlei de Oliveira ${ }^{1}$}

https://orcid.org/0000-0001-7261-6953

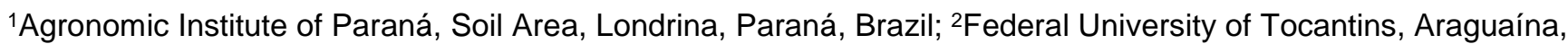
Tocantins, Brazil.
\end{abstract}

Received: 2019.09.16; Accepted: 2020.02.27.

*Correspondence: graziela_barbosa@iapar.br; Tel.: +55-43-33762120 (G.M.C.B.)

\section{HIGHLIGHTS}

- Use of poultry litter increased the productivity in sandy soils of the Northwestern of Paraná region

- Use of fertilized cover crops increase the sustainability of fragile soils.

- The contribution of the organic matter and nutrients to the soil increased the production of soybean and maize.

\begin{abstract}
The occupation of sandy soils in Brazil has occurred with poor adoption of management technology, which has caused its degradation. The recovery of organic matter, particularly when growing annual plants and cover crops, with mulch residue allows the maintenance of the productive potential of these soils. Thus, the shoot dry mass production (SDMP) of winter cover crops was evaluated in an Ultisol under no-tillage system and in rotation with soybean and maize using $0,2,4$ and $8 \mathrm{t} \mathrm{ha}^{-1}$ year ${ }^{-1}$ of poultry litter, mineral fertilizer exclusively and $2 \mathrm{t} \mathrm{ha}^{-1}$ year ${ }^{-1}$ of poultry litter associated with a half-dose of mineral fertilizer. The experimental design included randomized blocks with four replicates. The use of poultry litter increased the SDMP of the cover crops; the production was relatively high when high doses of poultry litter were applied; on the other hand, the yield of SDMP and grain was limited by the exclusive use of mineral fertilizer. Organic matter and nutrient status improvement by cover crops were one of the reasons for the increase in soybean and maize grain yields.
\end{abstract}

Keywords: sandy soils; organic matter; nutrient cycling; grain yield.

\section{INTRODUCTION}

Concern about sandy soils in Brazil has recently increased, as it has been occupied under a low level of management technology and degradation of these areas has occurred [1]. The ability of distinct soils to restore their productive capacity is different and dependent on their intrinsic properties and the type and 
intensity of disturbance. Some soils are more resistant to change, while others have a high potential for or a high risk of degradation, are extremely sensitive to disturbance and have very little of their natural condition restored. For this reason, they are called "fragile soils" or "light soils" [2,3].

Soil fragility is a relative concept, and each soil responds differently to external factors or forces that promote degradation. The use of the term fragile soil is not restricted to its agricultural occupation but also used in engineering works, the disposal of liquid or solid waste and other activities. In particular, these names are used for soils with very sandy texture, which favours erosive processes. They also have chemical fragility due to low organic matter content and low cation exchange capacity (CEC), as well as reduced aggregate stability and limited water storage capacity [2]. These soils are of great importance for the production systems, thus despite their weaknesses, the management adopted must consider the high degree of intrinsic fragility.

The use of sandy soils should include the establishment of production systems that consist of new arrangements or combinations of plants, which should provide productivity benefits and improve soil quality. Cover crops used for grain and fibre, the succession of forage grasses and legumes integrated with grain production, such as crop-livestock integration and crop-livestock-forest integration, and the use of forage grasses, including brachiaria, in rotation or succession with grain or fibre crops are technologies recommended for these fragile soils. Furthermore, mechanical and vegetative practices that contribute to the improvement of soil quality and erosion control can be used, given the intensification of land use, mechanization and the occurrence of erosive rainfall, which can accelerate the degradation process of these soils $[3,4]$.

In reporting the occurrence and importance of fragile soils in Brazil, Albuquerque and coauthors [2] highlighted the sandy soils of northwestern Paraná. Oxisols and Ultisols are the predominant soil classes in this region and have, good agricultural aptitude and high agricultural potential [4]. They are predominantly occupied by pastures (59\% of the area). In the last 15 years, an increase in the area of sugarcane, soybean, maize, and cassava has promoted a reduction in pastures acreage. This reduction occurred due to the lack of adoption of livestock technology and the consequent loss of profitability of activities. Pasture areas in the Caiuá Sandstone have always been used in an extractive manner, and $80 \%$ of them have some degree of degradation due to the lack of nutrient replacement in the soil and inadequate management of animals and forage species. Thus, the loss of vigour from pastures leads to soil degradation, the reduction of organic matter, soil compaction and erosion [5].

Ultisols from the northwestern region of Paraná are part of the group of soils with good agricultural aptitude; they are deep, usually of sandy or medium texture in the superficial layer and medium or clayey texture in deeper layers, and present a moderate impediment to drainage due to this textural gradient. Most soils have low natural fertility, with critical levels of phosphorus (P), potassium (K), calcium (Ca), and magnesium ( $\mathrm{Mg}$ ) and, often, low levels of organic matter (approximately 1\%); macro and micronutrient deficiency can often occur. The sandy contents reach $85 \%$ to $90 \%$ on the soil surface, and a lower content is observed in the textural B horizon, with abrupt transitions between them, creating a moderate impediment to vertical drainage, which makes them susceptible to erosion [4]. On the other hand, rainfall distribution in northwestern Paraná is another factor to consider when occupying the soil. In the wettest period (December, January, and February), precipitation is, on average, relatively high in the southwest than in the northwest; in contrast, in the driest period (June, July, and August), this trend occurs in the north-south direction of the region. Thus, in the eastern and southern parts of the state, there is a possibility to exploit short-cycle crops, while the centre and northwestern regions should be occupied with pastures and perennial crops [5].

These characteristics of the northwestern region of Paraná show that the cultivation systems must contemplate strategies that increase the organic matter, consequently, improving the physical, chemical and biological attributes of the soil; increasing the infiltration and water retention rates, as well as soil cation exchange capacity (CEC), which are essential conditions for cultivation in the region. This situation points to the appropriate use of organic fertilizers, such as animal manure, in these soils.

Poultry litter is available in the northwestern region of Paraná. The state is the largest producer (32\% of the volume produced) and exporter (34.4\% of the exported volume) of chicken meat in Brazil. The northwestern region of the state contributes approximately $10 \%$ of the slaughtered volume, which is associated with the north-central Paranaense region, totalizing $30 \%$ of the volume of chicken meat produced [6]. Assuming that, on average, with 42 days of rearing, $1.75 \mathrm{~kg}$ of dry litter per chicken is produced (7), and in 2014 , in the Northwest region, $10 \%$ of the chickens produced in the state $(152,918,794.00$ chickens) were slaughtered, the estimated production of poultry litter in the region would be 275 thousand tons. Using $4 \mathrm{tha}$ ${ }^{1}$ of poultry litter, this could cover an area of $68,750.00$ ha annually. 
The objective of the present work was to evaluate the rotational cultivation of cover crops and grain production in a no-tillage system using organic and mineral fertilizer to increase the productive potential of the sandy soils of the northwestern region of the state of Paraná.

\section{MATERIAL AND METHODS}

The experiment was carried out at the Agronomic Research Institute of Paraná State, Umuarama,

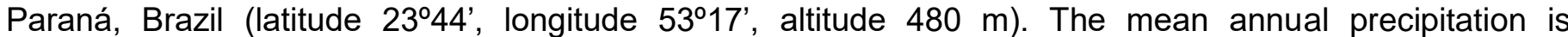
approximately $1623 \mathrm{~mm}$, and the climate is classified as humid mesothermic subtropical (Cfa), according to Köppen's classification. The soil of the experimental area is classified as Argissolo Vermelho distrófico arênico [8], typic Ultisol [9] with a sandy texture and a clay, silt, and sand content of 90,30 and $880 \mathrm{~g} \mathrm{~kg}^{-1}$, respectively, at 0.00-0.06 m in depth and 180,20 and $800 \mathrm{~g} \mathrm{~kg}^{-1}$, respectively, in the Bt horizon $(0.26-0.55 \mathrm{~m}$ in depth) [10].

In 2006 the experiment was installed under no-tillage system. Applications of poultry litter (PL) were initialized concomitantly with the adoption of this management. Over the eleven years, soybean (Glycine max L.) and maize (Zea mays L.) were used as summer crops and black oats (Avena strigosa, Schieb), vetch (Vicia sativa L.) and forage turnip (Raphanus sativus L.) were used as winter crops.

The treatments consisted of PL2, PL4, and PL8, corresponding to applications of poultry litter equivalent to 2, 4 and $8 \mathrm{t} \mathrm{ha}^{-1}$ year $^{-1}$, split with two applications: half was applied to the summer crop and half was applied to the winter crop. A total of 21,42 and $84 \mathrm{t} \mathrm{ha}^{-1}$ of $\mathrm{PL}$ was applied at the end of eleven years, respectively. Another two treatments, with mineral fertilizer (MF) and, poultry litter (PL2) associated with a half-dose of the MF (PL2MF1/2) were evaluated.

PL was applied in the months of September and April and it was applied manually on the soil surface without incorporation. For the mineral fertilization of maize, $20 \mathrm{~kg} \mathrm{ha}^{-1}$ of nitrogen $(\mathrm{N})$ was applied during seeding, and $60 \mathrm{~kg} \mathrm{ha}^{-1}$ was applied as the top dressing. For the cover crops, $20 \mathrm{~kg} \mathrm{ha}^{-1}$ of N was applied during seeding, and no fertilization was made to the top dressing, totalizing $400 \mathrm{~kg} \mathrm{ha}^{-1}$ of $\mathrm{N}$ in maize and $200 \mathrm{~kg}$ of $\mathrm{N}$ on cover crops over the period of the experiment (10 summer crops and 11 winter crops). The $P$ and $\mathrm{K}$ applications were similar between treatments that received mineral fertilizer, corresponding to $80 \mathrm{~kg}$ ha-1 of $\mathrm{P}_{2} \mathrm{O}_{5}$ and $60 \mathrm{~kg} \mathrm{ha}^{-1}$ of $\mathrm{K}_{2} \mathrm{O}$, totalizing $1680 \mathrm{~kg} \mathrm{ha}^{-1}$ of $\mathrm{P}_{2} \mathrm{O}_{5}$ and $1260 \mathrm{~kg} \mathrm{ha}^{-1}$ of $\mathrm{K}_{2} \mathrm{O}$. In PL2MF1/2 halfdoses of $\mathrm{N}, \mathrm{P}$ and $\mathrm{K}$ were applied.

In 2017, soil was sampled at depths of $0.00-0.10,0.10-0.20$ and $0.20-0.40 \mathrm{~m}$. The soil samples were airdried and sieved through a $2 \mathrm{~mm}$ mesh screen. Organic carbon, $\mathrm{pHCaCl}_{2}, \mathrm{Ca}, \mathrm{Mg}, \mathrm{K}, \mathrm{P}, \mathrm{Al}$ and $(\mathrm{H}+\mathrm{Al})$ were determined according to Pavan and coauthors [11]. The organic carbon content was determined via the wet oxidation method of Walkley-Black; $\mathrm{pHCaCl}_{2}$, with $\mathrm{CaCl}_{2} 0.01 \mathrm{~mol} \mathrm{~L}^{-1}$ at a proportion of 1:2.5 (m:v). Ca, $\mathrm{Mg}$ and $\mathrm{Al}$ were extracted with $\mathrm{KCl} 1 \mathrm{~mol} \mathrm{~L}^{-1}$ at a 1:10 ratio $(\mathrm{m}: \mathrm{v})$. Ca and $\mathrm{Mg}$ were determined by atomic absorption spectrophotometry, Al was determined by titration with $\mathrm{NaOH} 0.015 \mathrm{~N}$, potential acidity $(\mathrm{H}+\mathrm{Al})$ was determined by pHSMP, from the calibration curve for Paraná soils, and $\mathrm{K}$ was extracted by Mehlich-I and determined by flame photometry. The CEC, sum of bases (SB) and, BSP were calculated.

The shoot dry mass production (SDMP) of black oats in 2007, 2010, 2014, 2015 and 2016; black oats + vetch in 2008; and black oats + forage turnip in 2013 were evaluated. Three $0.5 \mathrm{~m} \times 0.5 \mathrm{~m}$ squares were randomly harvested from each plot before killing the cover crop by applying glyphosate. The shoot dry mass was manually cut by at the soil level, dried at $65^{\circ} \mathrm{C}$ to a constant mass and weighed. From these samples, shoot dry mass production (SDMP) of the cover crop was determined and extrapolated by hectare. SDMP of the winter and summer cover crops were left on the soil surface in accordance with the no-till premise, keeping the soil covered. The maize and soybean yields $\left(\mathrm{t} \mathrm{ha}^{-1}\right)$ were determined in subplots of 36 and 18 $\mathrm{m}^{2}$, respectively. Three subplots were harvested to compose a composite sample by plot.

In 2016, we evaluated the nutrient concentrations present in the shoot dry mass production of black oat. The samples were collected as described for shoot dry mass determination. Nitrogen $(\mathrm{N})$, phosphorus $(\mathrm{P})$ and organic carbon $(\mathrm{OC})$ were extracted from $\mathrm{HCl} 1 \mathrm{M}$ and determined by ICP-OES. Nitrogen was extracted by sulphur digestion $\left(\mathrm{H}_{2} \mathrm{SO}_{4}\right)$ and determination by spectrophotometry. Accumulated $\mathrm{N}, \mathrm{P}, \mathrm{K}$ and $\mathrm{C}$ were obtained by multiplying the nutrient content of a given treatment by the respective shoot dry mass production, resulting in values reported as $\mathrm{kg} \mathrm{ha}^{-1}$.

ANOVA was performed using SISVAR 5.6. Homoscedasticity and normality were evaluated by Bartlett's and Shapiro-Wilk's tests, respectively, and were obeyed. The mean values were compared using the ScottKnott test $(p<0.05)$ and orthogonal contrasts. Regression models were used to observe the relationship between grain yield and the production of shoot dry mass. 


\section{RESULTS AND DISCUSSION}

\section{Production of shoot dry mass}

The production of shoot dry mass of the winter cover crops in the no-tillage system was influenced by the interaction between treatments (poultry litter applications and mineral fertilizer) and years of cultivation (Table 1). Plant growth and development were influenced by the edaphoclimatic conditions prevalent in the culture medium. The use of organic or mineral fertilizer can make the soil suitable for cultivation. The weather has physiological importance, affecting the vegetable metabolic processes with a direct ecological interference in ecosystem formation and agronomic development, which defines crop yield [12].

Table 1. Production of shoot dry mass of the cover crops as a function of the poultry litter doses and the mineral fertilizer, including seven years of grown out of 11 years of the no-tillage system.

\begin{tabular}{|c|c|c|c|c|c|c|c|}
\hline \multirow{2}{*}{${ }^{1}$ Treatment } & 2007 & 2008 & 2010 & 2013 & 2014 & 2015 & 2016 \\
\hline & \multicolumn{7}{|c|}{${ }^{2}$ Shoot dry mass production $\left(\mathrm{t} \mathrm{ha}^{-1}\right)$} \\
\hline 0 & $1.79 \mathrm{a}$ & $3.73 \mathrm{~b}$ & $5.17 \mathrm{~d}$ & $4.28 \mathrm{~d}$ & $6.52 \mathrm{~d}$ & $3.73 \mathrm{c}$ & $3.18 \mathrm{c}$ \\
\hline PL2 & $2.17 \mathrm{a}$ & $6.13 \mathrm{a}$ & $9.17 \mathrm{c}$ & $8.66 \mathrm{c}$ & $10.52 \mathrm{~b}$ & $6.93 \mathrm{~b}$ & $5.74 \mathrm{~b}$ \\
\hline PL4 & $2.60 \mathrm{a}$ & $6.61 \mathrm{a}$ & $11.69 \mathrm{~b}$ & $10.67 \mathrm{~b}$ & $12.34 \mathrm{~b}$ & $7.89 a$ & $7.66 \mathrm{a}$ \\
\hline PL8 & $2.92 \mathrm{a}$ & $8.03 \mathrm{a}$ & $15.20 \mathrm{a}$ & $14.20 \mathrm{a}$ & $14.35 \mathrm{a}$ & $8.70 \mathrm{a}$ & $8.02 \mathrm{a}$ \\
\hline & $2.421 \mathrm{a}$ & $7.43 \mathrm{a}$ & $9.30 \mathrm{c}$ & $7.48 \mathrm{c}$ & $9.19 c$ & $6.71 \mathrm{~b}$ & $5.24 b$ \\
\hline PL2MF1/2 & $2.81 \mathrm{a}$ & $6.71 \mathrm{a}$ & $10.52 \mathrm{c}$ & $10.60 \mathrm{~b}$ & $11.27 \mathrm{~b}$ & $8.24 \mathrm{a}$ & $5.82 \mathrm{~b}$ \\
\hline${ }^{3}$ Mean & $2.45 \mathrm{E}$ & $6.44 \mathrm{D}$ & $10.18 \mathrm{~A}$ & $9.31 \mathrm{~B}$ & $10.70 \mathrm{~A}$ & $7.03 \mathrm{C}$ & $5.94 \mathrm{D}$ \\
\hline CV (\%) & 11.60 & 7.85 & 12.39 & 11.69 & 8.67 & 14.82 & 22.90 \\
\hline${ }^{3} \mathrm{~F}$-value & $8.75^{\star *}$ & $34.71^{* *}$ & $27.37^{* *}$ & $38.15^{\star *}$ & $33.54^{\star *}$ & $11.78^{* *}$ & $6.68^{* *}$ \\
\hline
\end{tabular}

${ }^{1} 0=$ no fertilizers (mineral or organic); PL2, PL4, PL8 = application of 2, 4 and $8 \mathrm{t} \mathrm{ha}^{-1}$ year $^{-1}$ of poultry litter, respectively; $\mathrm{MF}=$ mineral fertilizer with applications of 80 and $60 \mathrm{~kg} \mathrm{ha}^{-1}$ year-1 of $\mathrm{P}_{2} \mathrm{O}_{5}$ and $\mathrm{K}_{2} \mathrm{O}$, respectively, and nitrogen according to crop necessity; PL2MF1/2 = application of $2 \mathrm{t}$ of poultry litter associated with $40 \mathrm{~kg}$ of $\mathrm{P}_{2} \mathrm{O}_{5}$ and $30 \mathrm{~kg}$ of $\mathrm{K}_{2} \mathrm{O}$ ha $^{-1}$ year-1. $^{-1}$.

${ }^{2}$ In 2007, 2010, 2014, 2015 and 2016, black oat was sown, in 2008, a mix of black oat + vetch was sown; and in 2013, a mix of black oat + forage turnip was sown.

${ }^{3}$ Means with different letters; lowercase letters in columns and uppercase letters in rows indicate significant differences by Scott-Knott test $(p<0.05)$, and the symbol ${ }^{* *}$ indicates a significant difference at a $1 \%$ probability.

The significant interaction between the applications of mineral and organic fertilizers and shoot dry mass production over the years can be justified, in part, by edaphoclimatic alterations during the 11 years evaluated.

The control (0) showed relatively low shoot dry mass production (SDMP) from the second year when black oat + vetch was sown, regardless of cover crop (alone or combined), suggesting that the use of fertilizers had a positive effect on the SDMP of the cover crops (Table 1). In this year, no difference in SDMP was observed between treatments that received organic or mineral fertilizers.

The production of shoot dry mass by black oat in 2010 was high, showing that the weather condition of this winter was favourable to vegetal production. The relatively high dose of poultry litter (PL8) followed by 4 $\mathrm{t} \mathrm{ha}^{-1}$ year $^{-1}$ of PL (PL4) led to relatively high shoot dry mass production, and the opposite was observed in the treatment with no fertilizers (0), which had relatively low productivity (Table 1); the lower dose of poultry litter (PL2), the mineral fertilizer (MF) and the PL associated with mineral fertilizer (PL2MF1/2) treatments significantly increased the shoot dry mass production in relation to the treatment with no fertilizers $(0)$. In 2010, the benefits of poultry litter applications began to appear in relation to the mineral fertilizer (Table 1).

A high yield of shoot dry mass production (SDMP) was obtained in 2013 with the cultivation of the mix of black oat + forage turnip as cover crop, showing that the species mix is an alternative to use for soil vegetable cover, as observed previously [13]. Relatively high yields were observed in PL8, PL4, and PL2MF1/2. Furthermore, from this year, the exclusive use of fertilizer (MF) and the lower dose of poultry litter (PL2) showed an intermediate SDMP response, which was higher than that of the no fertilizer.

Black oat was sown alone in 2014, 2015 and 2016 as a winter crop, similar to 2007 and 2010. High yield was observed in 2014, with a mean for the different treatments of $10.70 \mathrm{tha}^{-1}$ of shoot dry mass production, suggesting satisfactory weather, particularly in terms of the amount and distribution of the precipitation, which enabled the proper development of black oats and the same productivity levels as those obtained in 2010. The black oat yield decreased in 2015, with a mean of $7.03 \mathrm{t} \mathrm{ha}^{-1}$ of shoot dry mass production and was even lower in 2016, with $5.94 \mathrm{t} \mathrm{ha}^{-1}$ (Table 1). Therefore, the black oat production was variable during the cultivation period, and the relatively low yields were limited mainly by weather conditions. 
The joint analysis of the mean results of shoot dry mass production for seven of the winter cover crops, sown in succession with soybean or maize, suggests that the use of $8 \mathrm{t} \mathrm{ha}^{-1}$ year-1 $^{-1}$ (PL8) of poultry litter promoted a relatively high yield, followed by applications of $4 \mathrm{t} \mathrm{ha}^{-1}$ year-1 and of $2 \mathrm{t} \mathrm{ha}^{-1}$ year $^{-1}$ associated with half the dose of mineral fertilizer (PL2MF1/2). The use of $2 \mathrm{t} \mathrm{ha}^{-1}$ year ${ }^{-1}$ of poultry litter (PL2) and of mineral fertilizer alone (MF) showed higher shoot dry mass productivity than that of the treatment without fertilizer (0). The productivity observed in PL8 was 2.5 times higher than that without fertilizer (0), while the productivity observed with mineral fertilizer increased 1.7 times, in relation to that without fertilizer (Figure 1). Therefore, continued and exclusive use of mineral fertilizer, in the doses applied, showed limitations in achieving more high shoot dry mass productivities of the cover crops, such as that observed when poultry litter was used.

Mulch production in the treatment with mineral fertilizer was $33 \%$ lower than that observed with $8 \mathrm{t} \mathrm{ha}^{-1}$ year $^{-1}$ (PL8) of poultry litter (Table 1 and Figure 1). After 18 years, the use of organic fertilizer increased shoot dry mass of black oat in relation to mineral fertilizer which, in turn, showed higher production than the treatment without fertilizer [14].

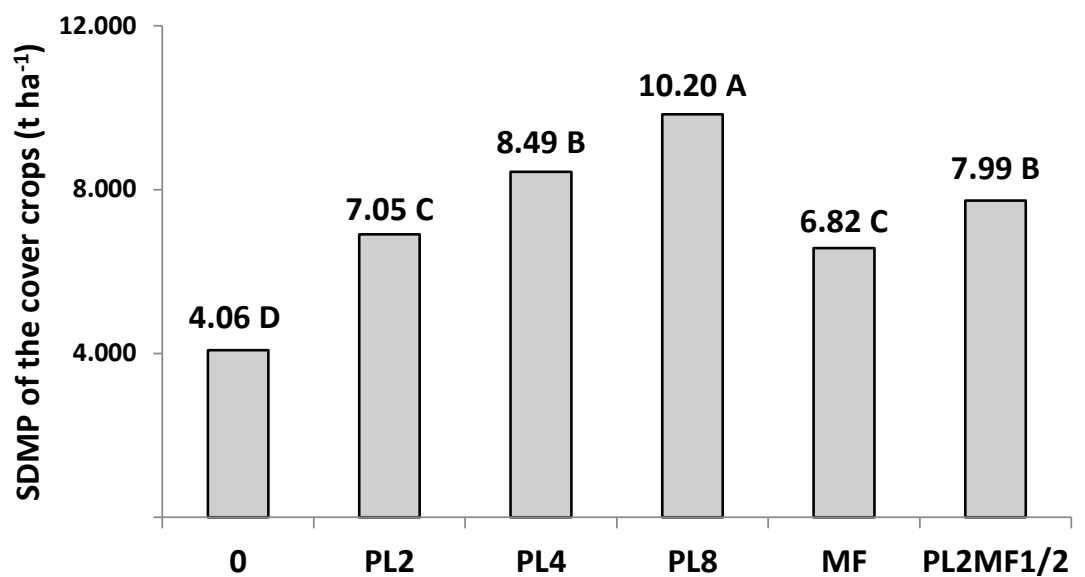

Figure 1. The mean shoot dry mass of production (SDMP) of the seven cover crops $\left(t^{-1} a^{-1}\right)$ in Argissolo Vermelho distrófico without fertilizer (0) and with 2 (PL2), 4 (PL4) and 8 (PL8) t ha-1 year-1 of poultry litter, mineral fertilizer (MF) and a combination of $2 \mathrm{t} \mathrm{ha}^{-1}$ year-1 of poultry litter and a half-dose of mineral fertilizer (PL2MF1/2). Means with different letters represent significant differences according to the Scott-Knott test $(p<0.05)$

To validate and verify the no-tillage system (NTS), Canalli and coauthors [15] proposed the consideration of the NTS adoption time, crop rotation (amount, quality and frequency of shoot dry mass added to the soil), percentage of soil cover and carbon content as indicators of the system quality. Regarding the amount of crop residues added to the soil (in t ha ${ }^{-1}$ year $^{-1}$ ), the authors also considered the cultivation region in Brazil and proposed a lower mass input in the colder regions and a greater incorporation of dry mass in warmer regions. For a region of low altitude and transition between the south and Cerrado, such as the northwestern region of the Paraná state, it was assumed that an input of dry mass lower than $7.5 \mathrm{t} \mathrm{ha}^{-1}$ year-1 would decrease the quality of the production system. Dry mass production between 7.5 and $8 \mathrm{t} \mathrm{ha}^{-1}$ year-1 $^{-1}$ would keep the system stable, and production higher than $8 \mathrm{t} \mathrm{ha}^{-1}$ year-1 is sufficient for increasing the production system quality [15].

Considering the mentioned criteria, it was possible to verify that, over ten years, the rotation system between soybean and maize in the summer and cover crop and black oat in the winter, was not sustainable without mineral or organic fertilization, since the yield of this system was not higher than $6.5 \mathrm{t} \mathrm{ha}^{-1}$ year $^{-1}$ in any of the evaluate years, with an average of $4.0 \mathrm{t} \mathrm{ha}^{-1}$ year ${ }^{-1}$ for the seven years evaluated. The production system declined for treatments that received exclusively mineral fertilizer (MF) and those with applications of $2 \mathrm{t} \mathrm{ha}^{-1}$ year-1 of poultry litter (PL2), whose production was 6.8 and $7 \mathrm{t} \mathrm{ha}^{-1}$ year ${ }^{-1}$, respectively (Table 1 and Figure 1).

For treatments with $2 \mathrm{t} \mathrm{ha}^{-1}$ year-1 of poultry litter associated with a half-dose of mineral fertilizer (PL2MF1/2) and $4 \mathrm{t} \mathrm{ha}^{-1}$ year $^{-1}$ of poultry litter (PL4), the shoot dry mass production was approximately $8 \mathrm{t}$ ha $^{-1}$ year ${ }^{-1}$, which reached the threshold of management that promoted improved quality of the cultivated system. The production of shoot dry mass increased to $10 \mathrm{t} \mathrm{ha}^{-1}$ year $^{-1}$ when $8 \mathrm{t} \mathrm{ha}^{-1}$ year ${ }^{-1}$ of poultry litter was used, substantially improving the cultivation system in Ultisol (Table 1 and Figure 1). These results suggest that for the sustainability of annual plant cultivation in sandy soils of the northwestern Paraná region 
the cover crops should be properly fertilized and that the use of poultry litter has the potential to provide and maintain this sustainability to the grain production system in these soil types.

Increased grain production of soybean and maize showed a linear and positive relationship with increased shoot dry mass production of the cover crops maintained on the soil surface (Figure 2).

Grain production ranged from 2.70 to $3.92 \mathrm{t} \mathrm{ha}^{-1}$. An increase of $0.21 \mathrm{~kg}$ of soybean was observed to each $\mathrm{kg}$ of shoot dry mass added (Figure 2a). In sandy soils, the yield of soybean decreases with decreasing organic matter and CEC [16]. On the other hand, the sustainable viability of soybean cultivation in sandy soils is dependent on its total and permanent cover, either by cultivated plant or surface mulch. Land cover reduces evaporative water losses, which are important for soils with low water storage capacity, minimizes the effects of erosion, decreases surface sealing, improves soybean plantability and reduces weed emergence [17]. Therefore, the increase in shoot dry mass production of the cover plants following mineral and mainly organic fertilization is one of the reasons for the increase in soybean production.

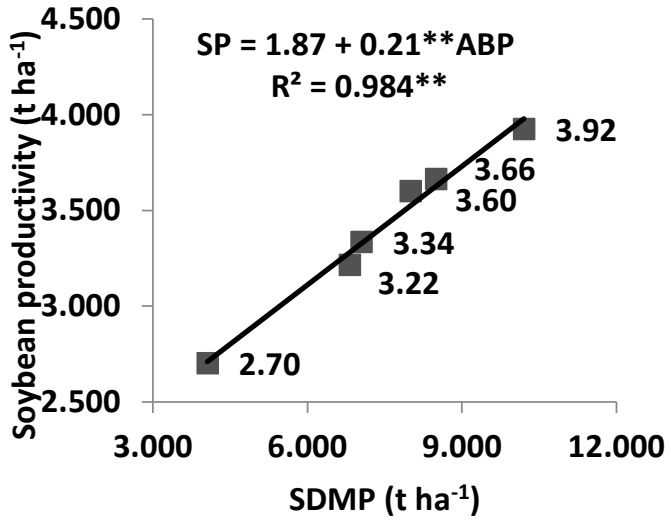

(a)

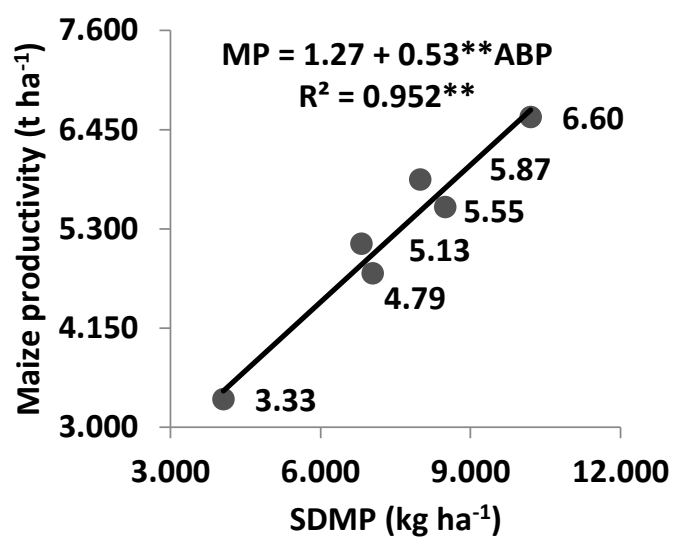

(b)

Figure 2. Relationship between shoot dry mass production (SDMP) of cover crops ( $t$ ha $^{-1}$ ) and soybean (a) and maize (b) productivity ( $\left.\mathrm{t} \mathrm{ha}^{-1}\right)$; an average of seven crops in Argissolo Vermelho were measured in Umuarama county.

The average yield of maize grain ranged from 3.33 to $6.60 \mathrm{t} \mathrm{ha}^{-1}$, depending on the amount of mulch added to the soil over ten years of cultivation. An increase of $0.53 \mathrm{~kg}$ of maize per $\mathrm{kg}$ of shoot dry mass was estimated (Figure $2 b$ ). These results suggest that when ground cover is insufficient, the productive potential of Ultisol under no-tillage system is limited by annual plant cultivation. On the other hand, the cultivation system that implements conservation practices over time, including crop rotation, which allows the intensive input and high quantities of crop residues, enables the recovery or maintenance of the sustainability of the production system. Production systems with a predominance of wheat-soybean or black oat-soybean (winter and summer crops) crops do not contribute to a positive soil carbon input. It would be positive if the system was associated with an intensive input of agricultural waste. The inclusion of maize, alone or in combination with pastures, is essential to keep the system stable [18].

Intensive growth and large amounts of shoot dry mass production (SDMP) from cover crops in Ultisol (Umuarama county) only occurred when organic or mineral fertilizer, was applied in adequate amounts, being $8 \mathrm{t} \mathrm{ha}^{-1}$ year $^{-1}$ to poultry litter (Figure 1). The increase in SDMP from these plants led to an increase in maize and soybean yields, indicating that the crop rotation system was adequate, although it does not include pasture.

\section{Soil attributes}

The soil organic carbon (SOC) content was significantly altered in the 0-10 cm depth after successive applications of poultry litter and mineral fertilizer over 11 years of the experiment. The highest SOC content was observed when applying the highest dose of poultry litter (PL8), and the lowest SOC content was found in the absence of fertilization (0) and with the exclusive use of mineral fertilizer (MF). The other treatments showed an intermediate position (Table 2). Therefore, increased doses of poultry litter increased the carbon input to the soil.

Carbon content was expected to increase with higher dose of poultry manure, but the initial SOC content determined at the beginning of the experiment, in 2006 , was $15.76 \mathrm{~g} \mathrm{~kg}^{-1}$ at a depth of $0-10 \mathrm{~cm}$ (Table 1) and the highest dose of poultry litter ( $8 \mathrm{t} \mathrm{ha}^{-1}$ year $\left.{ }^{-1}, \mathrm{PL} 8\right)$, after 11 years, approached the initial SOC content, with $15.13 \mathrm{~g} \mathrm{~kg}^{-1}$. The stimulate of microbial activity may explain the lack of an increase in carbon increment in 
the soil with poultry litter. The growth of decomposing organisms increases the mineralization of organic matter, which competes with the potential for poultry litter to promote an increase in soil carbon [19].

Table 2. Soil chemical attributes of the 0.00-0.10 m depth of an Ultisol (Umuarama, Paraná, Brazil). The evaluation was performed in October 2017, 12 years after the start of the treatment application.

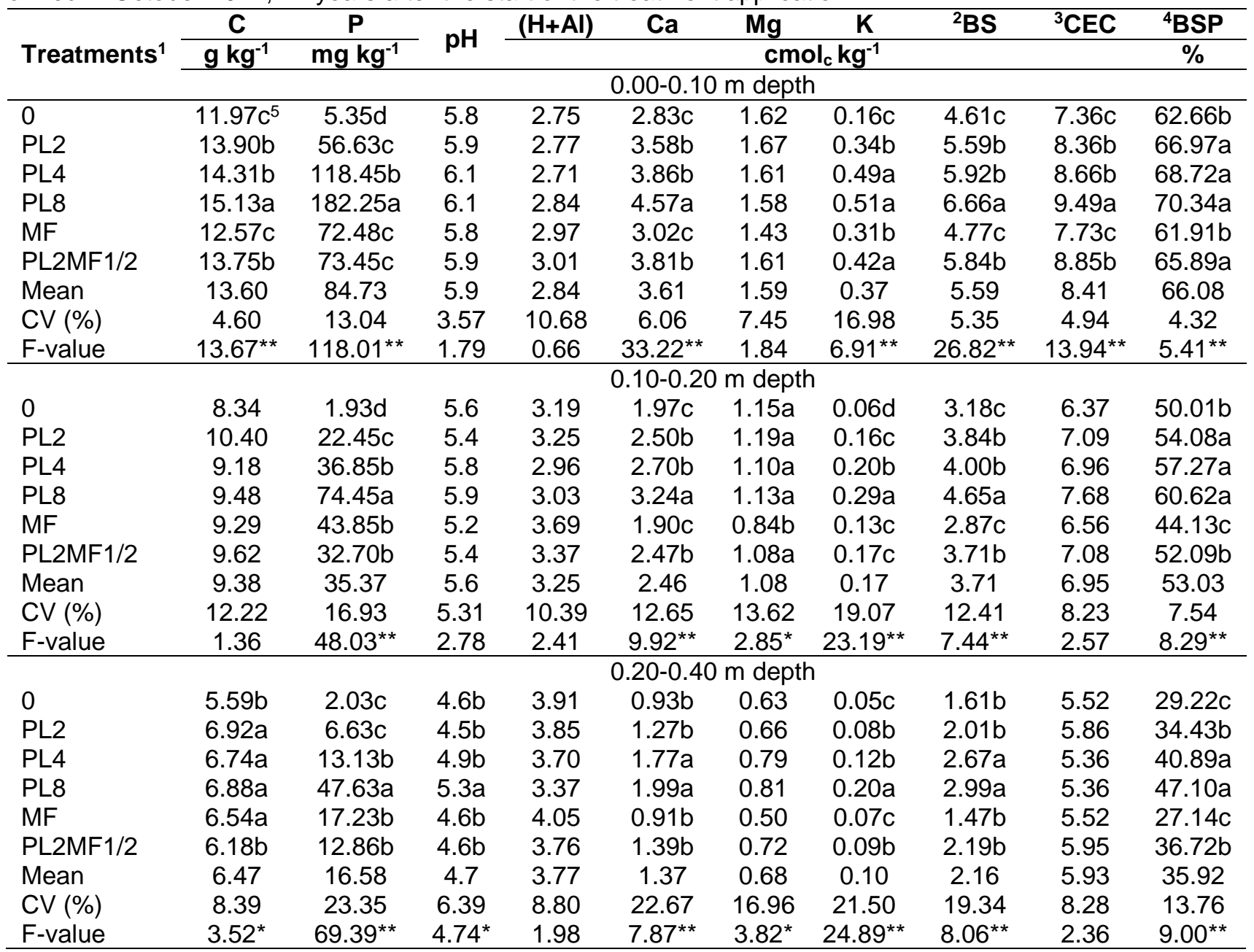

${ }^{10}=$ without mineral or organic fertilizer; PL2, PL4 and PL8 $=$ applications of 2, 4 and $8 \mathrm{t} \mathrm{ha}^{-1}$ year ${ }^{-1}$ of poultry litter,

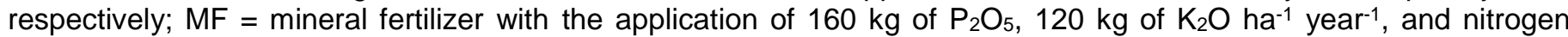
according to crop necessity; PL2MF1/2 = application of $2 \mathrm{t}$ of poultry litter associated with $80 \mathrm{~kg}$ of $\mathrm{P}_{2} \mathrm{O}_{5}$ and $60 \mathrm{~kg}$ of $\mathrm{K}_{2} \mathrm{O}$ ha $^{-1}$ year-1. $^{-1}$.

${ }^{2} \mathrm{BS}$, base saturation $\left(\mathrm{cmol}_{\mathrm{c}} \mathrm{kg}^{-1}\right)$.

${ }^{3} \mathrm{CEC}$, cation exchange capacity $\left(\mathrm{cmol}_{\mathrm{c} \mathrm{kg}}{ }^{-1}\right)$.

${ }^{4} \mathrm{BSP}$, base saturation percentage (\%).

${ }_{5}^{5}$ Means with different letters indicate significant difference based on the Scott-Knott test $(p<0.05)$.

While the mean dry matter content in poultry litter, after the rearing of 7 to 8 chicken lots, is $75 \%$, and the organic carbon content in this dry mass is $25 \%$ [20], it can be concluded that $187.50 \mathrm{~kg}$ of organic carbon are incorporated for each ton of litter "in natura" added to the soil per $750 \mathrm{~kg}$ of dry matter. In this sense, the highest dose of poultry litter incorporated $8 \mathrm{t} \mathrm{ha}^{-1}$ of organic fertilizer into the soil from 2006 to 2017. Therefore, exclusively due to litter, $16.5 \mathrm{t} \mathrm{ha}^{-1}$ of carbon were applied to the soil. In the evaluation period, there was also input from soybean and maize crop residues in the summer and the dry mass of cover crops in winter. The carbon content was increased to $3.16 \mathrm{~g} \mathrm{~kg}^{-1}$ at the $0.00-0.10 \mathrm{~m}$ depth when comparing the absence of fertilization (0) and the highest dose of poultry litter (PL8, Table 2). Therefore, $19.15 \%$ of the total carbon incorporated into the soil was due to by the highest dose of poultry litter.

At the 0.10-0.20 m depth, no difference was observed in the carbon content as a function of the applied treatments. From the calculations described above, it was found that the application of the highest dose of poultry litter (PL8) increased the carbon content to $1.14 \mathrm{~g} \mathrm{~kg}^{-1}$ at this depth when compared to that of nonfertilized treatment (0). In contrast, soil carbon contents increased in $0.20-0.40 \mathrm{~m}$ depth in treatments that received poultry litter and mineral fertilizer exclusively (Table 2). Fertilization increased the shoot dry mass production of cover crops by up to 2.5 times the average of (Figure 1). Root mass production must also have 
been increased, particularly black oats are recognized for their aggressive and deep root system [21]. Therefore, the root system mass of the cover crops may have contributed to incorporating and increasing the carbon content in the subsurface soil layers at depths of 0.10-0.20 and 0.20-0.40 m.

The orthogonal contrasts method allowed us meet and detail one of the objectives of this study, which was to compare the effects of different sources of fertilization, i.e., organic, mineral or the combination of them, on soil carbon content.

The average carbon content was higher on the surface, at $13.75 \mathrm{~g} \mathrm{~kg}^{-1}$, decreasing to $9.38 \mathrm{~g} \mathrm{~kg}^{-1}$ in the $0.10-0.20 \mathrm{~m}$ depth and to $6.47 \mathrm{~g} \mathrm{~kg}^{-1}$ in the $0.20-0.40 \mathrm{~m}$ depth (Table 2). The use of mineral or organic fertilizer increased the carbon content of the $0.00-0.10 \mathrm{~m}$ depth in relation to that of treatment without fertilizer (Table $3)$. At this depth, the average carbon when using mineral fertilizer was lower than that of the average in the treatments that used poultry litter. Therefore, fertilization increased the carbon input in the soil by increasing the production of plant residues in the area, especially when applied as poultry litter.

Adopting a probability of $F \leq 0.064$, it was observed that the soil carbon contents, at the $0.10-0.20 \mathrm{~m}$ depth, were lower in the absence of fertilization (0) when compared to those of the treatment that received mineral or organic fertilizer; no differences were observed at this depth between the fertilizer treatments. Additionally, at a $0.20-0.40 \mathrm{~m}$ depth, the lowest soil carbon content was observed in the treatment that did not receive mineral or organic fertilizer. Therefore, the carbon increase in the Ultisol (Umuarama, Paraná, Brazil) was dependent on the application of mineral or organic fertilizer. Even in the no-tillage system, there was, in the evaluated profile, an increase in the carbon content because of the use of organic or mineral fertilizers, which was probably due to the effect of these fertilizers on the increase in plant root production during the cultivation period (Tables 2 and 3 ).

Table 3. F-values and respective probabilities from the analysis of variance of orthogonal contrasts evaluated for the average carbon content in the soil treatment without fertilizer and those that received mineral or organic fertilizers.

\begin{tabular}{lccc}
\hline \multicolumn{1}{c}{${ }^{1}$ Contrasts } & \multicolumn{3}{c}{ Depth $(\mathrm{m})$} \\
\cline { 2 - 4 } & $0.00-0.10^{2}$ & $0.10-0.20^{2}$ & $0.20-0.40^{2}$ \\
\hline 0 VS PL2, PL4, PL8, & $32.941^{* *}$ & 3.991 & $12.693^{\star *}$ \\
MF, PL2MF1/2 & $(0.000)$ & $(0.064)$ & $(0.003)$ \\
MF VS PL2, PL4, PL8 & $26.946^{\star *}$ & 0.362 & 0.931 \\
& $(0.000)$ & $(0.556)$ & $(0.350)$ \\
PL2MF1/2 VS PL2, PL4, PL8 & 3.691 & 0.011 & 4.466 \\
& $(0.074)$ & $(0.919)$ & $(0.052)$ \\
MF VS PL2MF1/2 & $7.127^{*}$ & 0.166 & 0.879 \\
& $(0.017)$ & $(0.690)$ & $(0.363)$ \\
\hline
\end{tabular}

${ }^{1} 0=$ without mineral or organic fertilizer; PL2, PL4 and PL8 $=$ applications of 2,4 and $8 \mathrm{t} \mathrm{ha}^{-1}$ year-1 of poultry litter, respectively; MF = mineral fertilizer, with application of $160 \mathrm{~kg}$ of $\mathrm{P} 2 \mathrm{O} 5,120 \mathrm{~kg}$ of $\mathrm{K}^{2} \mathrm{O} \mathrm{ha}^{-1} \mathrm{year}^{-1}$; and nitrogen according crop necessity; PL2MF1/2 = application of $2 \mathrm{t}$ of poultry litter associated with $80 \mathrm{~kg}$ of P2O5 and $60 \mathrm{~kg}$ of K2O ha ${ }^{-1}$ year1 .

${ }^{2}$ The symbols ${ }^{* *}$ and ${ }^{*}$, next to each F-value, indicate significant differences at the $p<0.01$ and $p<0.05$ probability, respectively.

Cumulative applications of poultry litter and mineral fertilizer for 11 years increased extractable $\mathrm{P}$ (Mehlich-1) in this soil. Changes occurred at all evaluated depths. The highest P content was observed in the superficial layer (0.00-0.10 m), and the highest poultry litter doses were applied (Table 2).

Continued use of the highest dose of the poultry litter increased significantly the available $P$ content, exceeding more than 7.5 times the nutrient levels considered high for sandy soils, such as the Ultisol of the experimental area [20]. The no-disturbance of soil in the cropping system adopted in the experiment is the justification for the increased soil surface $P$ values [22].

At the $0.10-0.20$ and $0.20-0.40 \mathrm{~m}$ depths, the extractable $P$ contents were higher in the treatments that received mineral or organic fertilizers when compared with those in the absence of fertilization (Table 2), indicating $\mathrm{P}$ mobility over the evaluated profile. This movement, for subsurface layers, has already been observed by Ceretta and coauthors [23] in sandy soil with $150 \mathrm{~g} \mathrm{~kg}^{-1}$ of clay content. In soils with high levels of adsorption capacity and phosphate binding energy, the vertical mobility of $P$ is difficult. In soils with relatively low clay content, the adsorption surface saturation with relatively low doses of $P$ provided greater desorption and increased the downward movement in the soil. On the other hand, the addition of manure into the soil promotes greater P mobility in the profile in the form of soluble organic phosphate [24]. According to Cassol and coauthors [25], approximately $1 / 4$ of the total $P$ of broiler manure and $1 / 6$ of dairy cattle manure are organic fractions. In addition, continued cultivation of the area for 11 years, during summer and winter, 
produced high amounts of shoot dry mass, which not only recycled nutrients at the surface but also produced root mass that distributed nutrients deep into the soil. This association of factors may justify the increase in phosphorus levels observed in the Ultisol profile as a function of the application of both organic and mineral fertilizer (Table 2).

The sum of bases (SB) decreased with soil depth, however, they increased with the application of organic fertilizer to the soil. The use of mineral fertilizer (MF) did not increase the SB in relation to treatment without fertilizer (0). Therefore, the presence of organic fertilizer increased the sum of bases in the soil, and this increase was greater in the highest doses of poultry litter applied (Table 2).

Calcium and potassium were the nutrients that contributed the most to the SB increase, in the three layers evaluated, when poultry litter was applied. The magnesium contribution was not significant. Poultry litter applied over the years in the experiment had an average composition of 26.5, 19.2, 27.4, 29.7 and 6.9 $\mathrm{g} \mathrm{kg}^{-1}$ of $\mathrm{N}, \mathrm{P}, \mathrm{K}, \mathrm{Ca}$ and $\mathrm{Mg}$, respectively. The lower concentration of $\mathrm{Mg}$ in the manure may justify the lower content in the soil. The value of the soil base saturation percentage (BSP\%) had similar behaviour to SB as this value is directly associated with SB (Table 2).

The amount of cations adsorbed by the soil is represented by the cation exchange capacity (CEC) at pH 7.0. CEC values were increased by the application of organic fertilizer alone or in combination with mineral fertilizer (MF) at a depth of 0.00-0.10 m when compared to those of treatments without fertilizer and MF application. In this soil layer, the increase in T-value was proportional to the increase in the poultry litter dose applied (Table 2).

The application of poultry litter $(\mathrm{PL})$ in Ultisol increased the carbon input to the soil since carbon is a constituent of PL and, because of the effect on the increase in the production of vegetal residues originating from soybean and maize crops and, mainly, the cultivation of cover plants. Soil organic matter contributes 20 to $90 \%$ of the CEC of the surface layers of mineral soils. In tropical soils, with pH-dependent loads and clay fractions predominantly composed of kaolinite, iron and aluminium oxides, the contribution of soil organic matter is relatively high, especially in sandy soils [26]. Thus, the continued fertilization of the Ultisol was followed by an increase in production potential, with a notable increase based on the organic fertilizer and the inclusion of cover crops in a crop rotation system, which were cultivated under a no-tillage system.

\section{Nutrient cycling}

Organic matter deposition into the soil is a source of energy for microorganisms, which thus increases their mineralization activity and the nutrient availability to plants and, as a consequence, increases crop productivity [27].

Accumulated nitrogen in the shoot dry mass of black oat was higher in treatments that received the highest poultry litter doses, i.e., PL8 and PL4, as well as in combination with mineral fertilizer (PL2MF1/2). The lower litter dose (PL2) and the exclusive use of mineral fertilizer (MF) accumulated the same amount of $\mathrm{N}$ as that of the treatment without fertilization $(0)$ as shown in Figure 3 . The variation in accumulated $\mathrm{N}$ was proportional to the increase in the shoot dry mass production, provided by the organic fertilizer and the combination of organic and mineral fertilizer (Table 1 and Figure 1). The amounts of $\mathrm{N}$ accumulated in the PL8, PL4 and PL2MF1/2 treatments can be considered high when compared to those of other studies with black oats [14,28], but the presented $\mathrm{N}$ accumulation is compatible with the shoot dry mass production of black oat [21].

The lowest amounts of $P$ were observed in the treatment without fertilizer (0); the highest amounts occurred when higher doses of poultry litter were used. Borkert and coauthors [21] concluded that between macronutrients, phosphorus was the least recycled by black oats, ranging from 8 to $12 \mathrm{~kg} \mathrm{ha}^{-1}$ of $P$ when the shoot dry mass production ranged from 5 to $10 \mathrm{t} \mathrm{ha}^{-1}$. In the present study, in the Ultisol with sandy texture, low phosphate adsorption capacity and the high content of this nutrient, i.e., up to $182.25 \mathrm{mg} \mathrm{kg}^{-1}$ at the 0.00 $0.10 \mathrm{~m}$ depth (Table 2), an accumulation of $37.9 \mathrm{~kg} \mathrm{ha}^{-1}$ was observed (Figure 3) when shoot dry mass production was $8 \mathrm{t} \mathrm{ha}^{-1}$ in 2016 (Table 1). 


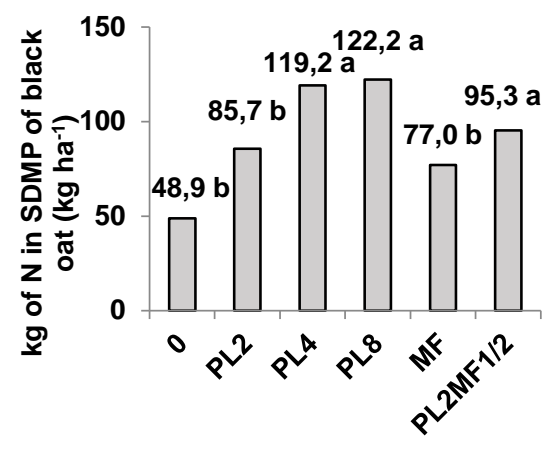

(a)

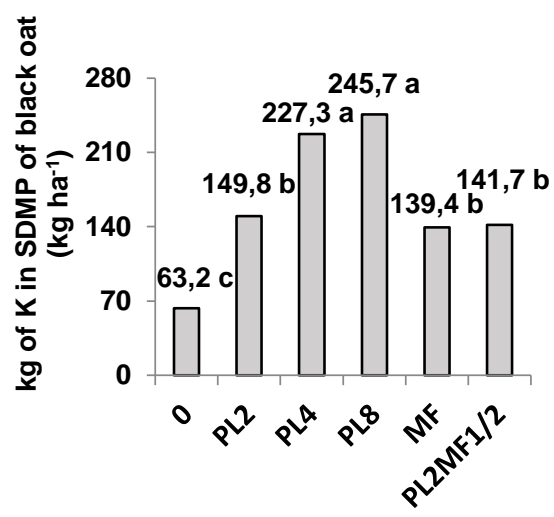

(c)

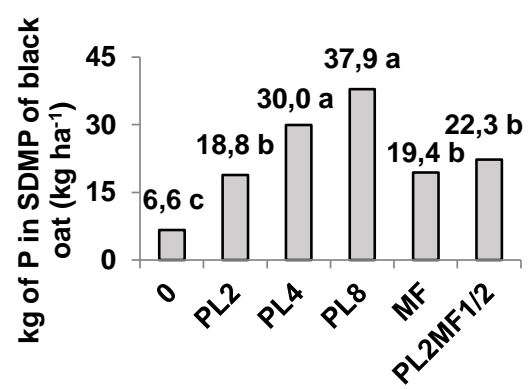

(b)

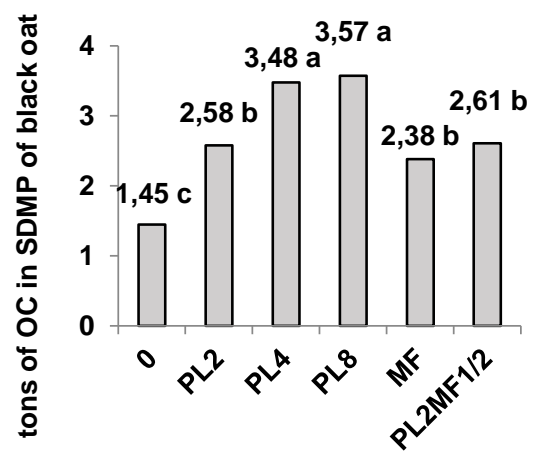

(d)

Figure 3. Nitrogen $(N)(a)$, phosphorus $(P)(b)$, potassium $(K)(c)$ and carbon $(C)(d)$ accumulated in the shoot dry mass of black oat $\left(\mathrm{kg} \mathrm{ha}^{-1}\right)$ as a function of applications of 2 (PL2), 4 (PL4) and 8 (PL8) t ha-1 year-1 of poultry litter (PL), mineral fertilizer (MF) alone and MF in combination with $2 \mathrm{t} \mathrm{ha}^{-1}$ year-1 of poultry litter (PL2MF1/2). Different letters on the mean value bars indicate significant differences according to the Scott-Knott test $(p<0.05)$.

Potassium was the most accumulated nutrient in the shoot dry mass of black oat. The highest concentrations occurred when the highest doses of poultry litter, PL8 and PL4, were applied. In the absence of fertilization (0), the lowest potassium accumulation in the shoot dry mass of black oat was observed. Potassium levels in the soil increased with continued fertilization, especially when the highest doses of PL were applied. The contents were higher in the soil surface, i.e., at the 0.00-0.10 m depth; however, an increase was observed in another three depths up to $0.40 \mathrm{~m}$ deep as a function of organic or mineral fertilization (Table 2). Black oats have a deep root system that can recycle $\mathrm{K}$ from subsurface soil layers, reducing nutrient losses from leaching [21], especially in sandy soils with low cation retention capacity.

From an evaluation carried out in 2016, it was observed that the use of higher doses of poultry litter, i.e., PL8 and PL4, increased the carbon concentration in black oats and, consequently, the carbon input to the soil; this effect was observed throughout the soil profile evaluated (Figure 3 and Table 2). At the highest doses of poultry litter, the amount of carbon added to the soil was 2.5 times higher than that of the treatment without fertilizer (0) (Figure 3).

Plant nutrient accumulation is dependent on and directly proportional to soil fertility, which determines the dry mass production by plants. Under conditions of soil nutrient deficiency, mass production and nutrient accumulation can be very low [14]. On the other hand, adverse weather conditions and inadequate crop management, negatively affect black oat mass production, regardless of soil fertility conditions [29]. The increase in organic matter and nutrient input to the soil by cover crops and organic and mineral fertilizer was one of the reasons for the increase in the productive potential of the grain cultures in Ultisol in the northwestern region of Paraná.

\section{CONCLUSION}

The use of poultry litter increased the shoot dry mass yield of cover crops; the production was higher when a larger dose was applied. The exclusive use of mineral fertilizer has limitations in reaching high dry mass yields. Soil fertilization improved soil carbon, phosphorus, and base sum levels, and this improvement 
was most noticeable with the use of poultry litter at the highest dose of $8 \mathrm{t} \mathrm{ha}^{-1}$. The increase in the contribution of organic matter and nutrients to the soil increased the soybean and corn grain yields.

Funding: This research received no external funding

Conflicts of Interest: The authors declare no conflict of interest. The funders had no role in the design of the study; in the collection, analyses, or interpretation of data; in the writing of the manuscript, or in the decision to publish the results.

\section{REFERENCES}

1. Dematte JLI. Principais desafios para o manejo sustentável de solos arenosos do Brasil. Csota ACS da, Muniz AS, Tormena CA, Cezar E, Gomes FH, Silva FC, et al., editors. REUNIÃO PARANAENSE DE CIÊNCIA DO SOLO, 5. SIMPÓSIO BRASILEIRO DE SOLOS ARENOSO, 2. Maringá, PR: SBCS/NEPAR; 2017. 14-19.

2. Albuquerque JA, Almeida JA de, Gatiboni LC, Rovedder AP, Costa F de S. Fragilidade de solos: uma análise conceitual, ocorrência e importância agrícola para o Brasil. In: CASTRO SS de, HERNANI LC, editors. Solos frágeis: caracterização, manejo e sustentabilidade [Internet]. Brasilia, DF: Embrapa; 2015. p. 25-50. Available from: https://www.embrapa.br/solos/busca-de-publicacoes/-/publicacao/1039217/ solos-frageis-caracterizacaomanejo-e-sustentabilidade

3. Donagemma GK, Freitas PL De, Balieiro FDC, Fontana A. Caracterização, potencial agrícola e perspectivas de manejo de solos leves no Brasil. Pesq. Agropec. Bras. 2016;51(9):1003-20.

4. Santos LM. dos, Matsushita MS, Bognola IA. Aptidão e potencial de uso dos solos do Estado do Paraná. In: Matsushita MS, editor. Trabalhos de Extensão Rural com uso de Geoprocessamento. Curitiba: Instituto Emater; 2014. p. 265-363.

5. Lugão SMB, Costa MAT, Gobbi KF. Integração pecuária-lavoura na região do Arenito Caiuá. In: Reunião Paranaense de Ciência do Solo. 3rd ed. Londrina, PR: IAPAR/ NEPAR; 2013. p. 469-81.

6. Sindiaviapar. Anuário Paranense de Avicultura 2015 [Internet]. SINDICATOS DAS INDÚSTRIAS DE PRODUTOS AVÍCOLAS DO ESTADO DO PARANÁ. 2015 [cited 2018 Jun 5]. Available from: http://www.sindiavipar.com.br/pdfs/folder-2015.pdf

7. Fukayama EH. Características Quantitativas e qualitativas da cama de frango sob diferentes reutilizações: Efeitos na produção de biogás e biofertilizante. Universidade Estadual Paulista "Júlio de Mesquita Filho"; 2008.

8. Santos HG, Jacomine PKT, Anjos LHC, Oliveira VA, Coelho MR, Lumbrelas JR, et al. Sistema Brasileiro de Classificação de Solos. 2nd ed. Rio de Janeiro: EMBRAPA-SPI; 2006. 306 p.

9. Staff SSD. Soil Survey Manual [Internet]. 12th ed. Service U-NRC, editor. Soil Conservation Service. U.S. Department of Agriculture Handbook. Washington, DC; 2014. Available from: http://soils.usda.gov/technical/manual/

10. Fidalski J, Tormena CA, Silva ÁP da. Least limiting water range and physical quality of soil under groundcover management systems in citrus. Sci Agric. 2010;67(4):448-53.

11. Pavan MA, Bloch MFM, Zempulski HC, Miyazawa M. Manual de análise química de solo e controle de qualidade. Inst Agronômico do Paraná - Circ 76. 1992;39.

12. Lopes NF, Lima M da GS. Fisiologia da Produção. Viçosa UF de, editor. Viçosa, MG; 2015. 492 p.

13. GIACOMINI SJ, AITA C, VENDRUSCOLO ERO, CUBILLA M, NICOLOSO RS, FRIES MRM. Matéria seca, relação $\mathrm{C} / \mathrm{N}$ e acúmulo de nitrogênio, fósforo e potássio em misturas de plantas de cobertura de solo. Rev. Bras. Cienc. Solo. 2003;27(2):325-34.

14. Melo AV de, Galvão JCC, Braun H, dos Santos MM, Coimbra RR, Silva RR da, et al. Extração de nutrientes e produção de biomassa de aveia-preta cultivada em solo submetido a dezoito anos de adubação orgânica e mineral. Semin Ciências Agrárias. 2011;32(2):411-20.

15. Canalli LB, Sá JC de M, Santos JB dos, Ferreira AO, Briedes C, Tivet F, et al. Proposta de um protocolo para validação e certificação da qualidade do SPDP relacionada à redução de CO2. In: ENCONTRO NACIONAL DE PLANTIO DIRETO NA PALHA. 13th ed. Ponta Grossa, PR: FEBRAPDP; 2010. p. 85-94.

16. Silva JE da, Lemainski J, Resck DVS. Perdas de matéria orgânica e suas relações com a capacidade de troca catiônica em solos da região de cerrados do oeste baiano. Rev. Bras. Cienc. Solo. 1994;18:541-7.

17. Franchini JC, Balbinot Junior AA, Debiasi H, Costa JM, Sichieri FR, Teixeira CT. Soja em solos arenosos: papel do sistema plantio direto e da integração lavoura-pecuária. Londrina: Embrapa - Soja; 2016. 10 p.

18. Sá JCM, Sá MFM, Santos JB, Oliveira A. Dinâmica da matéria orgânica nos Campos Gerais. In: Santos GA, Silva LS, Canellas LP, Camargo FAO, editors. Fundamentos da matéria orgânica no solo: ecossistemas tropicais e subtropicais. 2nd ed. Ponto Alegre, RS: Metropole; 2008. p. 443-61.

19. Ashworth AJ, DeBruyn JM, Allen FL, Radosevich M, Owens PR. Microbial community structure is affected by cropping sequences and poultry litter under long-term no-tillage. Soil Biol Biochem. 2017;114:210-9.

20. SBCS - Nucleo Regional Sul C de Q e F do S. Manual de calagem e adubação para os Estados do Rio Grande do Sul e Santa Catarina. Curitiba. Curitiba: SBCS/Núcleo Regional Sul; 2016. 376 p.

21. Borkert CM, Gaudêncio CA, Pereira JE, Pereira LR, Oliveira Junior A. Nutrientes minerais na biomassa da parte aérea em culturas de cobertura de solo. Pesq. Agropec. Bras. 2003;38(1):143-53. 
22. Ceretta CA, Basso CJ, Vieira FCB, Herbes MG, Moreira ICL, Berwanger AL. Dejeto líquido de suínos: I-Perdas de nitrogênio e fósforo na solução escoada na superfície do solo, sob plantio direto. Cienc. Rural. 2005;35(6):1296304.

23. Ceretta CA, Durigon R, Basso CJ, Barcellos LAR, Vieira FCB. Características químicas do solo sob aplicação de esterco líquido de suínos em pastagem natural. Pesq. Agropec. Bras. 2003;38:729-35.

24. Novais RF, Smyth TJ. Fósforo em solo e planta em condições tropicais. Viçosa, MG: Universidade Federal de Viçosa; 1999. 399 p.

25. Cassol PC, Gianello C, Costa VEU. Frações de fósforo em estrumes e sua eficiência como adubo fosfatado. Rev Bras. Cienc. Solo. 2001;25:635-44.

26. Silva IR da, Mendonça ES. Matéria Orgânica no solo. In: Novais RF, Aalvarez V, Barros NF, Cantarutti RB, Neves JCL, editors. Fertilidade do Solo. Viçosa, MG: SBCS - Sociedade Brasileira de Ciência do Solo; 2007. p. 275-374.

27. Heckler JC, Salton JC. Palha: fundamento do sistema plantio direto. Dourados: Embrapa Agropecuária; 2002. 26 p.

28. Ceretta CA, Basso CJ, Herbes MG, Poletto N, Silveira MJ. Produção e decomposição de fitomassa de plantas invernais de cobertura de solo e milho, sob diferentes manejos da adubação nitrogenada. Cien. Rural. 2002;32:4954.

29. Crusciol CAC, Moro E, Lima E V., Andreotti M. Taxas de decomposição e de liberação de macronutrientes da palhada de aveia preta em plantio direto. Bragantia. 2008;67(2):261-6.

( 2020 by the authors. Submitted for possible open access publication under the terms and conditions of the Creative Commons Attribution (CC BY NC) license (https://creativecommons.org/licenses/by-nc/4.0/). 